MAGNETIC DISTURBANCE AT TIME OF ERUPTION OF MONT PELÉE.*

CoIncident, as far as can be at present ascertained, with the time of eruption of Mont Pelée on May 8 , a magnetic disturbance set in which was registered on the self-recording instruments of the two U. S. Coast and Geodetic Survey magnetic observatories, the one at Cheltenham, Md., seventeen miles southeast of Washington, and the other at Baldwin, Kansas, seventeen miles south of Lawrence. The preliminary reports received from $\mathrm{Mr}$. L. G. Schultz, in charge of Cheltenham observatory and Mr. W. C. Bauer, in charge of Baldwin Observatory are sufficient to indicate that the disturbance began at practically the same instant of time at both observatories, viz., at 7h. 54m. St. Pierre local mean time. According to the newspaper reports the catastrophe befell St. Pierre about 8 A.M. of May 8 and it has been stated that the town clock was found stopped at $7 \mathrm{~h} .50 \mathrm{~m}$.

Purely mechanical vibrations caused by earthquakes are often recorded by the delicately suspended magnetic needles, as for instance the Guatemalan one which was felt at the Cheltenham Observatory on April 18 from about $9 \mathrm{~h} .20 \mathrm{~m}$. to $9 \mathrm{~h} .50 \mathrm{~m}$. P.M., 75th meridian mean time. time stated and continuing until midnight of the 9 th. Even on the 10th tremors were still discernible. (At the time of writing the subsequent curves had not yet been received.)

Until further information has been received from other observatories, it cannot be determined definitely whether this magnetic disturbance was due to some cosmic cause or came from within the earth's crust and was associated with the Martinique eruption. The coincidence in time is however a remarkable. fact.

\section{U. S. Coast and Geodetic Survey,} L. A. Bauer. May $17,1902$.

\section{THE GUATEMALA EARTHQUAKE WAVES OBSERVED} IN CANADA BY R. F. STUPART.

To the Editor of Science: By permission of Professor R. F. Stupart, Director of the Meteorological Service of Canada, I send you herewith seismograms (Milne system) of April 18, local reckoning, recorded at Victoria, B. C., and Toronto, Canada; also a print of the magnetogram (bifilar trace) at Agincourt, nine miles from Toronto.

Each of these records the earth billows. emanating from the region of the recent earthquake in Guatemala. Professor Stupart states

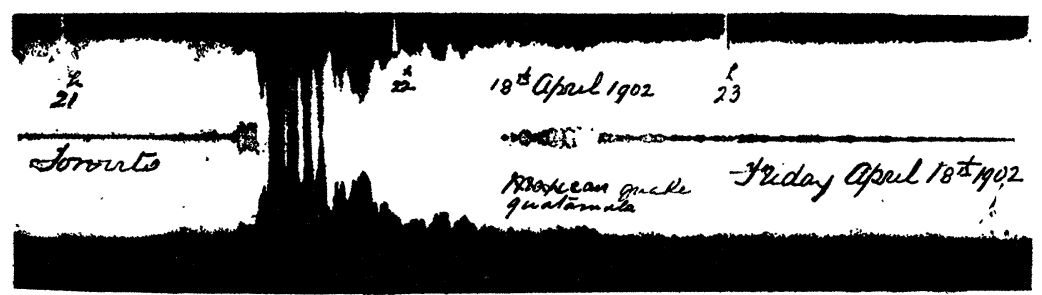

FIG. 1. Record of Milne Seismograph, Toronto, April 18, 1902.

The disturbance on May 8, however, was distinctively a magnetic and not a seismic one and hence was not recorded on seismographs. The Cheltenham magnetograms exhibit magnetic disturbances amounting at times to .00050 to 0.00060 c. g. s. units (about $1 / 350$ of the value of the horizontal intensity) and from $10^{\prime}$ to $15^{\prime}$ in declination, beginning at the

* Communicated by permission of Superintendent O. H. Tittmann, Coast and Geodetic Survey. that "the preliminary tremors began at Toronto 2 h. 30.5 m. A.M., April 19 of Greenwich mean time, and at Victoria 2 h. 31.3 m., G. m.t. Large waves began at Toronto $2 \mathrm{~h} .35 .5 \mathrm{~m}$., but at Victoria $2 \mathrm{~h} .37 .2 \mathrm{~m}$. The maximum wave occurred at Toronto $2 \mathrm{~h} .38 .0 \mathrm{~m}$., but at Victoria 2 h. $50.7 \mathrm{~m}$. The end ocćurred at Toronto $5 \mathrm{~h} .24 .0 \mathrm{~m}$., but at Victoria about 5 h. $36.4 \mathrm{~m}$. The amplitude at Toronto was over $25 \mathrm{~mm}$. 
"In the magnetic observatory at Agincourt, nine miles from Toronto, the bifilar magnet began to swing at $2 \mathrm{~h} .35 .0 \mathrm{~m}$., Greenwich mean time, and was at its maximum swing at 2 h. $44.4 \mathrm{~m}$. Facsimiles of the records at Toronto, Victoria and Agincourt are given in the accompanying figures, Nos. 1, 2, 3, respectively."

C. A.

WASHINGTON, May 7, 1902. canaliculi in specimens injected in the laboratory of the late Professor Rutherford, of Edinburgh.

Some time ago the writer was at work on the vascular supply of the chief organs of vertebrates. In the course of these studies, many, probably fifty, injections were made with gelatine-carmine, well acidulated, of the livers of the rabbit, rat, cat and other mammals. The injection was made through the portal vein in every instance. The most painstaking

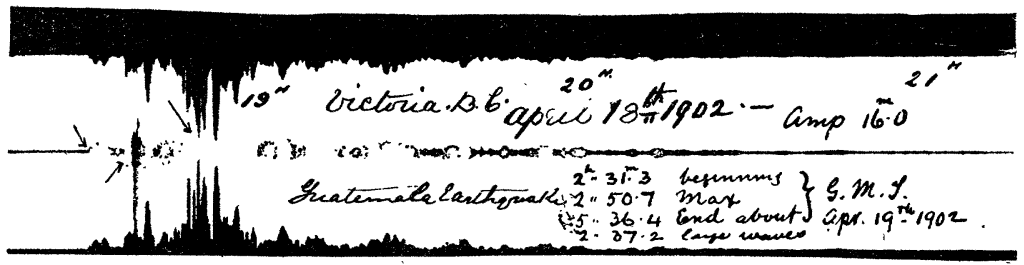

Fig. 2. Record of Milne Seismograph, Victoria, April 18, 1902.

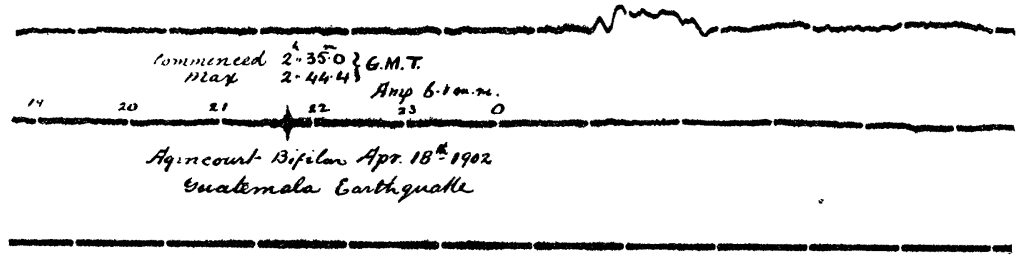

FIG. 3. Record of the Bifilar and other Magnets, Agincourt, April 18, 1902.

\section{SHORTER ARTICLES.}

INTRACELLULAR GANALICULI OF THE LIVER.

THE cells of the liver in one of the higher vertebrates are characterized by activities at once numerous and diverse. It should not be surprising therefore if a specialized mode of communication were found between the hepatic cells and the blood capillaries with which they are related. Such a connection has, in fact, been predicted.

In a series of studies published from Cracow, Browicz has indicated grounds for believing that minute channels exist in the cells of the liver, and that these are continuations of the vascular system. More recently, Schaefer* has noted the presence of such

* Schaefer, E. A., Anatomischer Anzeiger, 1902, Bd. 21, S. 18-20. precautions were always taken to secure the conditions which experience had shown to be necessary for proper injection, and some of the results were as nearly perfect as could be.

In sections made from successfully injected livers, the network of lobular capillaries is uniformly filled, there is no indication of extravasation, and the hepatic cells show no sign of distortion. In such specimens, exceedingly tenuous canaliculi may be seen within the cells, filled with the red injecting-mass, branching more or less, and anastomosing with each other. Under a high magnification, the blood capillaries do not present perfectly smooth walls, but exhibit minute, spine-like elevations at intervals. The connection between the intracellular canaliculi and the outpushings of the capillary wall may occa- 